International Journal of Social Science And Human Research

ISSN(print): 2644-0679, ISSN(online): 2644-0695

Volume 05 Issue 01 January 2022

DOI: 10.47191/ijsshr/v5-i1-28, Impact factor-5.586

Page No: 189-201

\title{
Unpacking the Paradox of Student-Involvement Quality Promotion Nexus: Knowing Where to Draw the Line and Implications Thereof
}

\author{
Mthuthukisi Ncube ${ }^{1}$, Francis Godfrey Ncube ${ }^{2}$, Excellence Charles Mateke ${ }^{3}$ \\ ${ }^{1}$ Lecturer and Researcher- Gwanda State University, Filabusi, Zimbabwe \\ ${ }^{1} \mathrm{PhD}$ Candidate- IDS- National University of Science and Technology, Bulawayo, Zimbabwe \\ Orcid id: 0000-0002-7178-5955 ${ }^{1}$ \\ ${ }^{2}$ Candidate for BEng. in Mining Engineering, Gwanda State University, Zimbabwe \\ ${ }^{3}$ Candidate of BEng. in Mining Engineering Student, (Gwanda State University, Zimbabwe)
}

\begin{abstract}
Student-involvement in higher-education is necessary for quality-assurance outcomes, yet such involvement also threatens attainment of quality assured, presenting the paradox of higher-education (HE) systems. With the massification of enrolment-figures across the HE sector has been the need to balance HEI and student-centred perspectives. The notion of students as co-producers, consumers, and products of HEI processes creates discord in the quality assurance arena. Contradictory problems manifest when the producer must satisfy the consumer and audit quality of the products, yet students are all of these. This article explored the extent to which student-involvement fosters quality as well as sets parameters beyond which such participation cannot be done without compromising quality-assurance and desired academic-success. The artile drew a line for student-involvement and quality- assurance as double-barreled and sometimes paradoxical, contradictory pursuits. Data elicited from two HEIs in Zimbabwe using the questionnaire method and analysed using Microsoft Excel package generated descriptive frequencies and related graphs and charts to present findings. Documents were analysed using thematic content analysis to glean for relevant secondary data. Student-involvement is marred by unclear parameters at the three confluences of 'students as co-producers'; 'students as consumers'; and 'students as products' of HEI quality-assurance processes students should participate in, consume, and be products of. Derolling is thus necessary for students to function in various capacities as as co-producers, consumers, or as products. Students as 'co-producers' cannot be expected to produce themselves through 'students as products', neither can they be 'consumers' themselves while being the 'product' to be consumed by industry and communities through employment and innovation. The National Assembly should address contradictions through amending HEI-establishing Acts to cede policy making powers to the University Councilsacting jointly with senior management of universities. As co-producers, students involvement should be unlimited at governance levels (by different HEI students) while as consumers (within particular HEIs), student involvement should be limited to lower rungs at consumer level to avoid contradictions that potentially compromise quality. As HEI products, students should be limited to Alumni activities as main function should clearly differentiate among the various roles when crafting HEI policies that foster student involvement.
\end{abstract}

KEYWORDS: higher-education-institutions, student-involvement, quality-assurance, students-as co-producers, paradox

\section{INTRODUCTION}

While autonomy in higher education opens it up areas for improvement and competition, the sector is restricted by the influence, which some argue is interference, of state-driven higher education policy and the constantly increasing intervention of external quality assurance (Kennedy 2003; Hénard and Mitterle 2008). Great importance is placed on the student experience in higher education (HE) today. Scott (2018) postulates national, and often international attention is on how students report their learning experience with institutions of higher education (HEI) providers often under pressure to demonstrate they have satisfied students' needs and interests (Scott 2018). Consequently, students are continually asked to feedback on their experience, and whether their expectations are being met with such feedback and satisfaction measures being used to assess quality in both academic and nonacademic aspects of the student experience within HEIs (Scott 2018).

The student as producer initiative at HEI explores possibilities for very different ways of working that genuinely enable studentdriven participation and democratic practice by realigning the student-lecturer nexus, challenging the power imbalance and moving 


\section{Unpacking the Paradox of Student-Involvement Quality Promotion Nexus: Knowing Where to Draw the Line and Implications Thereof}

"from traditional accountability to shared responsibility" (Cook-Sather 2009, 231-232). This paper draws on literature to critique and explore ways to strengthen the student voice and change lecturers-students relationships, reposition lecturers "with their students ... as partners in quality assurance processes" (Cousin 2008, 268); in this instance, the concerns of curriculum development, quality learning and teaching at a subject level. The paper initially sets out the broader context and wider debates that inform and influence participative practices as ways of involving students in quality improvement. The writer then explored the paradox arising from the arious partnership models used for student involvement where studets are seen as co-producers, consumers and products of HEI knowledge and processes at the same time.

\section{QUALITY ASSURANCE AND PROMOTION}

The purpose of 'quality assurance' in higher education according to BIS (2016) cited in Scott (2018) is providing evidence that standards of teaching and learning are being met. The Quality Assurance Agency (QAA) emphasized the need for evidence in their definition, 'At its core, the purpose of QA is to be transparent and to demonstrate quality in overt and measurable ways' (Barnes and Bohrer 2015, 63; cited in Scott 2018) although what 'quality' itself means in education has long been debated (Harvey and Williams 2010; Scott 2018). Harvey and Green (1993) identified five perspectives from which quality can be viewed: exceptional; perfection (or consistency); fitness for purpose; value for money; or transformation (cited in Scott 2018). A more focused definition by Cunningham $(2015,46)$ suggests 'quality in higher education exists when students are being effectively and efficiently provided with the teaching, resources, support and environment to allow them to achieve their full learning potential'. The two definitions by Harvey and Green (1993) and that by Cunningham (2015) shall jointly underpin this study because of the relevance of their joint components such as exceptional, perfection; fitness for purposes, value for money and transformative as well as the aspect of effectiveness and efficiently providing teaching, resources, support, and environment to achieve full potential. The former definition addresses intrinsic while the latter addresses extrinsic student involvement quality assurance factors in higher education.

Elevating student choice and satisfaction actually threatens restricting students' education experience (Staddon and Standish, 2012; Scott 2018) when satisfaction is less relevant than a student's sense of purpose and well-being. For those with a transformational view of education, measuring satisfaction is not meaningful as real intellectual gain is associated with challenge, discomfort, and even crisis (Staddon and Standish, 2012; Scott, 2018). It is thus likely a student at a difficult stage of the learning process is unlikely to present as 'satisfied', even though high quality learning may actually be taking place (Bramming, 2007; Elwick and Cannizzaro, 2017; Hamshire et al., 2017; Richardson, 2005; Scott, 2018). Therefore expecting students to be satisfied at all times is unrealistic, as education is meant to be unsettling (Hamshire et al., 2017; Scott, 2018), 'disruptive to norms'. Encouraging students to challenge their HEIs to provide good quality is questioned (Williams 2013; Scott, 2018). The basis is that it has negative effects lecturerstudent relationships and their institution (Williams, 2013). Williams (2013:82) claims 'a pervasive sense that lecturers and students have opposing interests requires external regulation'.

Similarly, HEIs placing too much faith on students' ability decide on quality in areas like pedagogy, curriculum and strategy lack confidence in self, (Staddon and Standish, 2012; Scott 2018). Ramsden (2008) suggests students' expectations, prior to HE experience are often not fully formed, they do not have a coherent understanding of what it will entail (Scott, 2018). Students may only realise years after completing HE whether they gained what they needed from a programme. Thus, encouraging them to believe they can make choices based only on their initial expectations is not only unrealistic, but also misleading (Bay and Daniel, 2001; Ness and Osborn, 2010). Such HEI is unlikely to provide a positive learning-teaching experience for either students or lecturers. While they see this lack of confidence as a problem, they point out that current policy distorts reality by encouraging it, promoting it as in the student interest. From the above arguments lies the paradoxical interests of student-involvement and quality assurance in the same breath.

\section{THE EXTENT OF STUDENT PARTICIPATION THAT FOSTERS QUALITY PROMOTION}

Debates and practices relating to improved student involvement have been gaining momentum since the mid-1990s and now go beyond individual student learning to involvement in structures and process at a subject, faculty and institutional level (Trowler 2010). Through their participation in an array of learning activities, students "co-produce" their education (HennigThurau et al. 2001 cited in Kotzé and du Plessis 2003). At the same time, they also contribute directly to their own satisfaction, quality and value perceptions (Bitner et al. 1997 cited in Kotzé and du Plessis 2003). The 2003 The future of higher education white paper describes the enhancement of teaching as "central to the purpose of higher education" (DfES 2003, 46). With the advent of criticism against teacher-focused transmission of information format (Light, Calkins \& Cox 2009 cited in Hynes 2018) and a shift to student-centred learning, what students do becomes as important for their understanding as what the teacher says (Hynes 2018). That way, students 


\section{Unpacking the Paradox of Student-Involvement Quality Promotion Nexus: Knowing Where to Draw the Line and Implications Thereof}

co-create knowledge as opposed to passively receiving information, and this encourages deep learning under the growth of 'studentcentered learning' as an alternative approach (Jonassen \& Easter 2012; McMahon \& O'Neill 2005; Race 2015; Hynes 2018).

Browne report developed an explicit focus on 'quality' and the development of "minimum levels of quality enforced through regulation" (Browne 2010, 2). Institutional governance fundamentally focuses on the quality assurance, control and enhancement of practices. Currently, quality assurance and enhancement are high on national agendas, with the process of assuring quality in HEIs under review and requiring the enhancement of standards of provision across all programmes. The literature shows that, in the UK, there have been moves towards placing more emphasis on the learner voice as a way of enhancing learning and increasing learner involvement (Little and Williams 2010). In addition, Coates describes involvement as "a broad construct intended to encompass salient academic as well as certain non-academic aspects of the student experience" (Coates 2007, 122). Alaniska and Eriksson (2006) cited in Roslöf (2018) discussed students' roles in the academic community. In order to achieve optimal results in there should be a collaborative culture of learning present in the higher education institutions (HEIs). The closer the students are involved in a department's activities the more open dialogue and better result for improvement. The students' involvement in QA activities can be divided in four categories (Alaniska \& Eriksson 2006; cited in Roslöf 2018):

1) Student as an information provider: Giving feedback in different forms is the most common way of engaging students in QA. A typical procedure is to ask feedback for every completed course or collect data every semester, for example. There is a multitude of ways to collect student feedback and both quantitative and qualitative methods are used (Roslöf, 2018).

2) Student as an actor: Students have potential to have a more active role than just the role of a source of data. The students can participate in designing the feedback questionnaires in cooperation with the academic staff and join the analysis of the collected data as well. Students can also organize workshops concerning different improvement topics where the issues can be discussed together with the staff members in a comfortable environment (Roslöf 2018).

3) Student as an expert: One of the focal points of QA in education should be the quality of learning - not teaching. The students are experts in their learning; they are able to reflect how (and if) they have reached the intended learning outcomes and how teaching has guided them in this process. Utilizing the students' expertise can be implemented by inviting them to join different working groups, meetings and seminars. Considering students as experts demands positive attitude both from the staff and from the students (Roslöf 2018).

4) Student as a partner: The partnership between students and staff refers to an authentic and constructive dialogue enabling reflective feedback. The common responsibility and ownership about the activities and their further development is recognized, and there is an easy-going atmosphere and culture in the department. Continuous cooperation and co-organization takes place leading to open and authentic QA and improvement (Roslöf 2018). Scott (2018) highlights a complexity that arises from the unequal yoking of students with their administrators and lecturers is that students often pay much attention to peripheral issues than the core, majoring the minor thereby. For example when students give feedback in meetings, they prioritize general issues like the food, the parking, condoms and sports entertainment as opposed to academic matters (Scott 2018). This tends to result in students voices being belittled due to their limited scope of focus that places emphasis on current rather than long term issues.

It could therefore be argued that meaningful student involvement in the quality processes is crucial to "enhance the collective student learning experience" (Little and Williams 2010, 119). A key component of student involvement is therefore the student voice and interaction in institutional governance, which can be found in student feedback, student representation, student approaches to learning, institutional organisation, learning spaces, architectural design and learning development (Trowler 2010). Presenting a case study report from Belgium, Wyns et al. (2015) cited in Roslöf (2018) posit student involvement at KU Leuven has long traditions, with every faculty having its own student organization and student representatives appointed annually through elections. Gvaramadze (2011) however questions the validity of some approaches to capturing the student voice, such as student satisfaction surveys, quantitative evaluation methods and performance indicators, but suggests that student engagement has the potential to redefine quality enhancement processes in HEIs. Similarly, Crawford argues that "commonly-used often managerialist performanceled approaches to gaining feedback on the student experience ... are at best impersonal, untimely and ineffective and at worst deskilling and devaluing of professional practice in higher education", and proposes a different way of working with students and academics as partners in a community of scholars (Crawford 2012, 52).

\section{THE MODELS OF PARTICIPATION THAT DRAW PARAMETERS TO STUDENT-INVOLVEMENT}

Lizzio and Wilson (2009) observe that the value of actively involving students in institutional governance can be classified according to one of three perspectives: functional (how it benefits the university); developmental (how it benefits the student); and social (how it benefits society). Furthermore, according to Trowler $(2010,1)$, who conducted an extensive literature review on student there is 


\section{Unpacking the Paradox of Student-Involvement Quality Promotion Nexus: Knowing Where to Draw the Line and Implications Thereof}

a substantial, robust body of evidence to support assertions that individual student involvement in educationally purposive activities leads to positive outcomes of student success and development. In an institution's commitment to improving student participation, benefits could be developed to drive an institutional culture to engage students in effective educational practices and experiences (Pascarella, Sefifert and Blaich 2010). It could be argued that, within a functional perspective, enhanced accountability in terms of policy and decision-making may result as a benefit of a more participative process (Sabin and Daniels 2001). Currently, student involvement in shaping the design and delivery of the curriculum tends to be mainly indirect through feedback surveys (Trowler and Trowler 2010, 14).

While institutions are becoming more aware of the purpose of surveys and evaluations (Nair, Bennett and Mertova 2010, 555), problems have been reported around closing the feedback loop and demonstrating the improvements made as a consequence of the quality cycle (Trowler and Trowler 2010; Nair, Bennett and Mertova 2010). Professionalism in students involved in dealing with matters like exam setting and invigilation has been of concern. Students are mostly excluded from matters like curriculum setting, exam setting and invigilation, which are things which determine the future of the students (Trowler and Trowler 2010). However, knowing where to draw a line is an answer in seeking quality assurance by students involvement. Trowler and Trowler (2010) suggest students doing the same programme from another HEIs, come and help in invigilating at another HEI. As a measure to try and minimise compromising the quality seeked, the student in invigilating put their certificates at stake if they are caught in any foul play. Cancellation of the invigilators' and exam-sitting student's certificate if caught in any foul play.

\section{THE ROLE OF THE STUDENT REPRESENTATIVE}

Student involvement beyond individual student learning can be classified in structure/process at a subject level through student representation: as consultants or as observers; as representatives; or as members of committees at course, departmental, faculty or institutional level (Trowler 2010). Lizzio and Wilson (2009) studied student representatives in university school committees to try to determine their conception of, motivation and preparation for and sense of efficacy in the representative role. In the study, Lizzio and Wilson $(2009,81)$ observe that students reported, on average, moderate to high levels of learning and development as a result of undertaking the representative role. The student representative role is potentially a rich context for learning across a number of different skills and additional domains. Yet the student representative role is complex. Democracy is very difficult to achieve: students use representation processes only if they have a problem; when things are satisfactory, they are difficult to engage in trying to improve things (Little and Williams 2010).

\section{MAKING CHANGE}

In their study, Umbach and Wawrzynski $(2005,173)$ conclude academic staff have a role to play in student involvement, stating that the educational context created by faculty behaviours and attitudes has a dramatic effect on student learning and engagement. Institutions where faculties create an environment that emphasises effective educational practice have students who are active participants in their learning and perceive greater gains from their undergraduate experience. While student involvement in quality processes is seen as a priority by most institutions, there are inevitably barriers and challenges to achieving student-lecturer partnerships and learner-centredness. Little and Williams (2010) identify that the majority of institutions still work on the basis of student as consumer.

In the consumerist perspective, HEIs act as providers of products such as academic programs and services (Gvaramadze 2011). Financial pressures, tuition fees and government impressions of universities all have a role to play in the cause of students viewing themselves as consumers. As a result, students may not feel that they can or even want to have a say in their learning, as they are led to believe that they are simply consumers (Little and Williams 2010). It is clear that a shift in student behaviour, from student as consumer to student as producer, would require a change in their relationships with institutional staff and in the culture of the institution as a whole. Students and their unions therefore have a key role in establishing better partnerships to achieve such a cultural shift (Little and Williams 2010).

A number of researchers have developed and tested models of the antecedents and consequences of customer socialisation and participation in service settings. These models were tested in contexts ranging from financial services (Kelley et al. 1992; Govender 1998) and grocery retailing (Bettencourt 1997) to charitable organisations (Cermak et al. 1994; Claycomb et al. 2001). However, despite the importance of student participation in the provision of educational services, similar models have not yet been tested in the context of tertiary education. This may be due to the fact that the relevance of services-marketing theory for tertiary institutions has only recently been acknowledged (Mazzarol and Soutar 1999; Hill 1995). The student as producer ambition is to get students to 'buy in' to this different approach, so that staff and students work together as partners in enquiry. Coates (2005) advises student involvement involves learning that is dependent not only on individual participation in educational activities but also on institutions and academics facilitating a shared and co-operative approach to the joint endeavour. 


\section{Unpacking the Paradox of Student-Involvement Quality Promotion Nexus: Knowing Where to Draw the Line and Implications Thereof}

Conversely, invitations to staff to become more collegial with students could be problematic, to the extent that collegiality may not necessarily be realised between staff themselves (Lizzio and Wilson 2009). The extent to which staff members are willing to engage in 'power sharing' is a key determinant of the success of this approach to student involvement and engagement. The student as producer or co-producer model conceptualises active student involvement in quality enhancement processes. Such a model shares responsibilities among students, academics and institutions in relation to the whole teaching and learning experience. The regard that students become partners or co-producers and engage in decision-making about teaching and learning goes well beyond a consumer-type relationship with students (Gvaramandze 2011).

Thus the development of a co-producer model through student involvement would directly impact on approaches to teaching and learning and links to quality enhancement processes in HEIs. Student involvement of this nature requires a change at an institutional level to decision-making and policy formation. The resulting changes at subject level will redefine the student-lecturer relationship and the provision of not just student involvement in quality processes but direct participation and membership of committees, review panels and validations. Coates (2005) identifies that there is a challenge here in reconciling the constructivist perspective underpinning the idea of student involvement with what is ultimately an institutional responsibility for managing ongoing improvement. It is apparent that quality assurance determinations must therefore take into account how and to what extent students engage within activities that are likely to lead to productive learning (Coates 2005). Gvaramadze (2011) goes further, advising that in order to effectively engage students with quality processes, it is necessary to make changes to the quality systems and processes that incorporate the student-lecturer partnership, learner-centredness, value added and the quality of the student learning experience.

Student involvement of this nature requires an institutional-level cultural change to decision-making and policy formation, namely, changes to the direct participation and membership of committees, review panels and validations. Currently, student participation on programme or departmental committees is found in several institutions in Zimbabwe but great variability exists at this level and there is little evidence as to the nature, function or quality of this form of engagement (Trowler and Trowler 2010, 14). If students and staff work in partnership to improve the learning experience in programmes or the work of departmental committees, there would be a number of key benefits, as outlined by Little and Williams (2010): student representatives would be able to comment on programme delivery and wider issues without being seen as threatening to staff or negatively affecting the students' academic performance; student representatives and staff would have a sense of shared responsibilities for a student's own learning and the learning of others on the same programme; and students would have an equal opportunity to have their voices 'heard'.

In addition, it has been demonstrated that the use of action research enables students to be far more open about what they think about their course and what they have gained from it (Gapp and Fisher 2006). However, action research is being delayed, for example in Zimbabwe in most HEIs it is being done in the final year of studies. It is therefore, encouraged that institutions should give their students tasks of action research at least in the second of their studies. It has also been noted that studies involving the student themselves actively engaged in the design and delivery of curriculum are conspicuously absent from the literature (Trowler and Trowler 2010). Furthermore there has also been a call for finer grained studies on student involvement in structures and practices, including student governance, student voices in curriculum shaping and the perennial problem of "closing the feedback loop" (Trowler 2010, 50).

\section{STATEMENT OF THE PROBLEM}

That students have a fully formed set of expectations prior to application (Ramsden 2008; Ness and Osborn, 2010; Bramming, 2007; Staddon and Standish, 2012; Biesta, 2015). That students should be encouraged to challenge their institution to provide good quality (Staddon and Standish, 2012; Williams, 2013). That quality is propped up through emphasis on student expectations and satisfaction data (Staddon and Standish, 2012; Cheng, 2017; Biesta, 2015; Ness and Osborn, 2010; Stroebe, 2016). Student, as producers, consumers and products of knowledge create discord in the quality assurance arena. Problems manifest as a paradox where the producer must satisfy the consumer and audit quality of the products, yet all are in one. Sharing responsibility between lecturers and students has been a matter of concern as the students are viewed as consumers not producers or co-producers. Lecturers and students working as colleagues in consulting and teaching can bring an untold fight as they would want to show off who is superior or better qualified than the other. As a point to note, lecturers themselves as staff members fail to work as colleagues, therefore the coming in of students has it's own challenges and also affairs might be promoted as the time spent together is increased. In addition, studentlecturer affairs can lead to sexually transmitted marks or leaking of the exam papers (Ncube 2019).

\subsection{Research Objectives and Questions}

The study sought to achieve the following objectives:

1. To establish the extent of student participation that fosters quality promotion

2. To describe models of participation that draw parameters to student-involvement 
Unpacking the Paradox of Student-Involvement Quality Promotion Nexus: Knowing Where to Draw the Line and Implications Thereof

\section{THEORETICAL FRAMEWORK: LADDER OF PARTICIPATION}
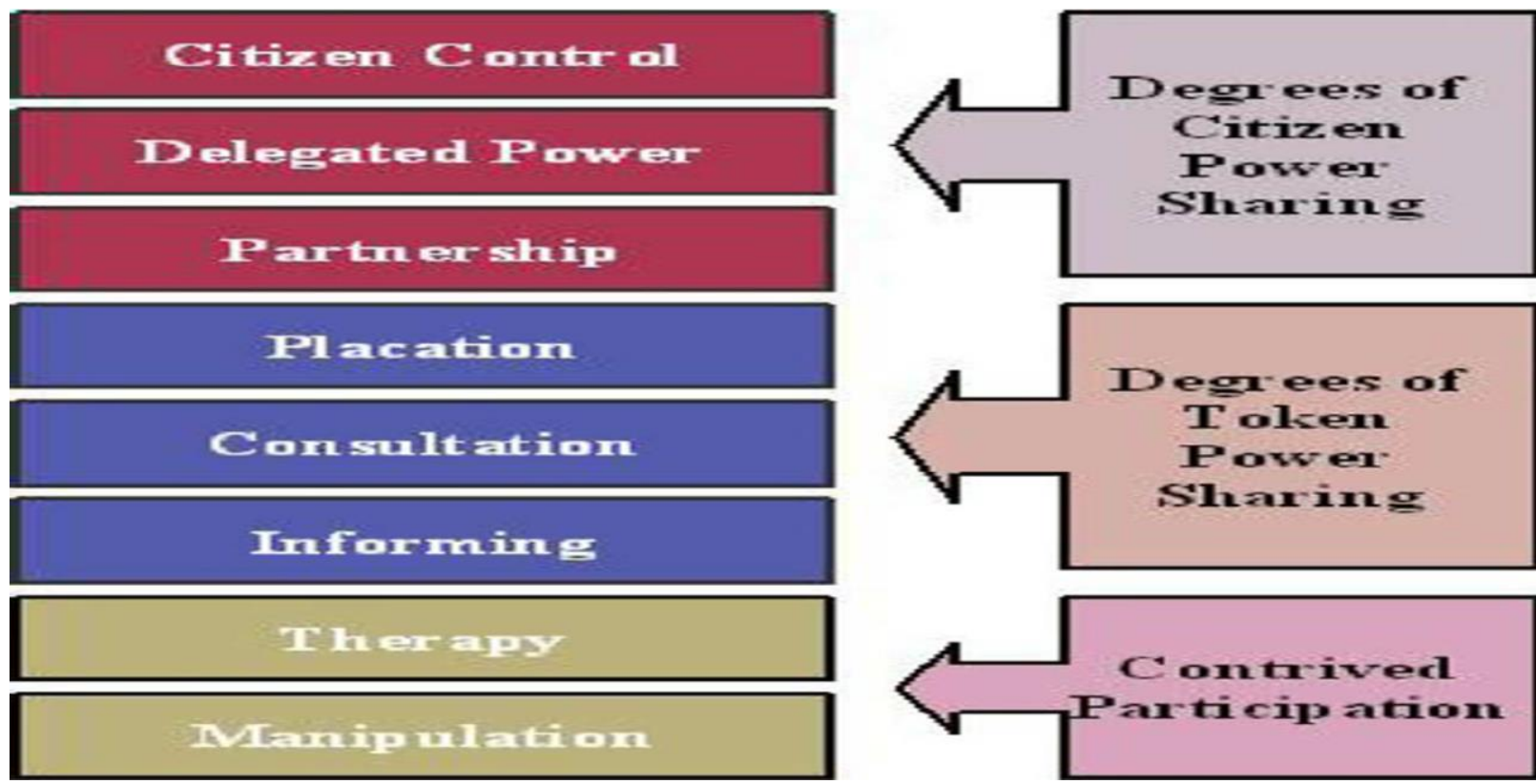

Results and Discussion: Student Participation that Fosters Quality Promotion

Fig. 2: Degree of Participation to Draw the Student-Involvement Line

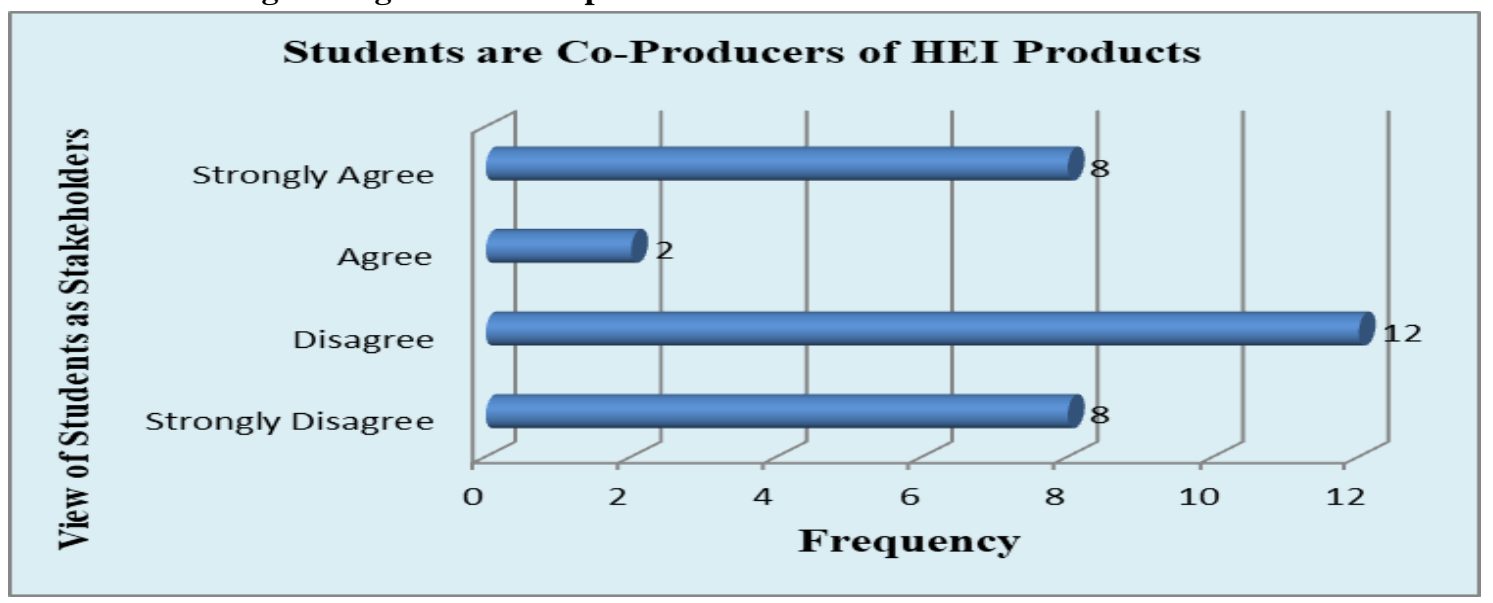

Asked the extent to which they agreed students should be involved in quality assurance processes as co-producers of HEI knowledge and products, respondents had contradictory responses. A significant twelve (12) 'disagreed' while eight(8) 'strongly disagreed'. These accounted for cumulative twenty who variously 'disagreed'. Eight (8) 'agreed' students are co-producers of HEI knowledge and graduates as products while two (2) 'strongly disagreed' with a cumulative ten (10) variously 'agreeing'. That more respondents disagreed with the argument that students are co-procuders of knowledge and products of HEIs contradicts submissions by Kotzé \& Du Plessis (2003) who, citing HennigThurau et al. (2001) posit that through their participation in an array of learning activities, students "co-produce" their education. That way, the scholars argue students also contribute directly to their own satisfaction, quality and value perceptions (Bitner et al. 1997 cited in Kotzé \& Du Plessis 2003). Scholars have variously argued that students have no capacity to participate equally as partners and co-producers of knowledge upon application for enrolment at HEIs hence their knowledge, capcity to contribute meaningfully should be guided and limited to classroom tasks and related learning as learning experts but cannot be unlimited. 
Fig. 3: Students as Consumers of HEI Knowledge and Products

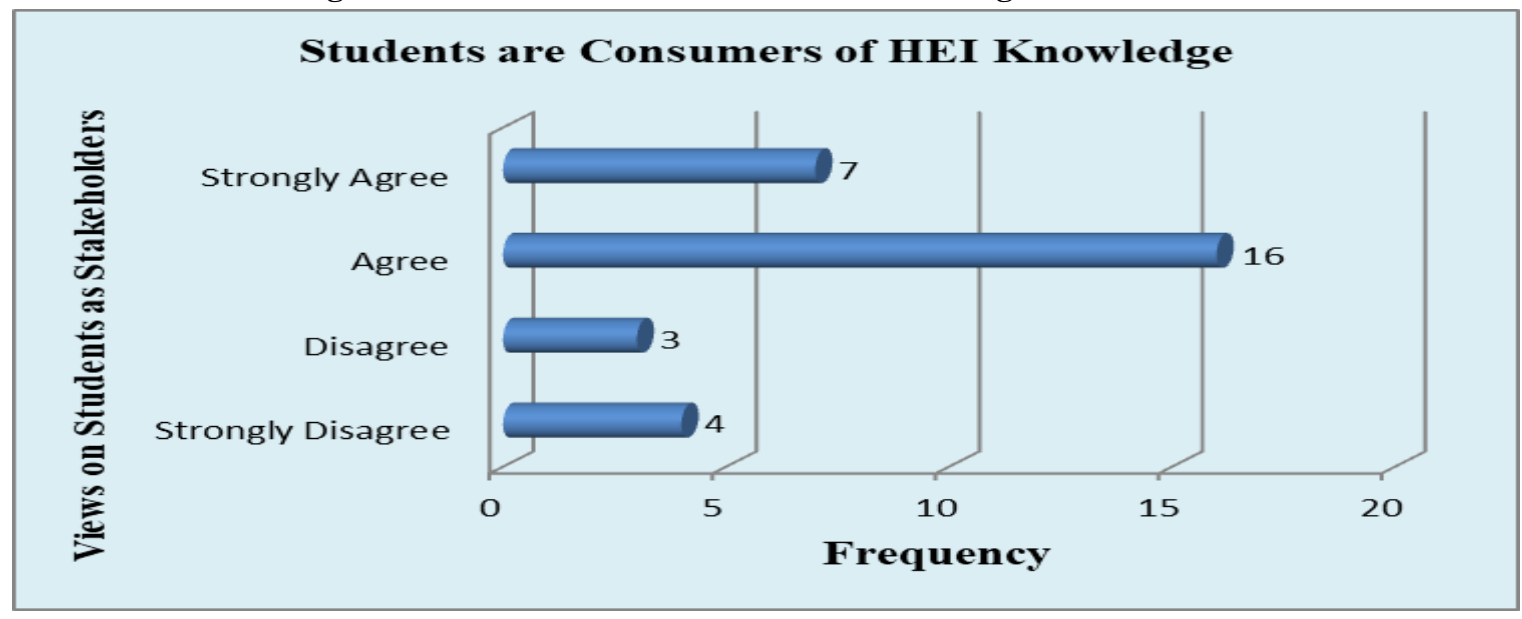

Depicted in Figure 3 above is a unanimously agreed position that respondents took where they variously agreed (seven 'strongly agreed' while sixteen 'agreed') students are consumers and not co-producers of knowledge and other HEI products. Arguments by Eagle and Brennan (2007) cited in Woodall, Hiller and Resnick (2011) whether students can be considered consumers is open to debate, but the deceptive inroad of the customer concept that students. The finding identifies students as 'customers' (Dearing 1997 cited in Bunce, Baird and Jones 2017), higher education institutions (HEIs) in England have increasingly had to operate under forces of marketisation which demand competitiveness, efficiency and consumer satisfaction (Lesnik-Oberstein 2015 cited in Bunce et al. 2017). Moreover, this consumer identity appears to be increasingly recognised by students, who demand more from the higher education sector than ever before (Kandiko and Mawer 2013; Tomlinson 2014, 2016 cited in Bunce et al. 2017). Paying money through fees in exchange for HEI services has also been shown to create feelings of entitlement among students, which are associated with higher levels of complaining (Finney and Finney 2010 cited in Bunce et al. 2017). The following figure 4 below buttresses the fiding that studets are largelu viewed as consumers and products of the HEI processes as opposed to being co-producers of such knowledge and products.

Fig. 4: Students are Products of HEI Knowledge

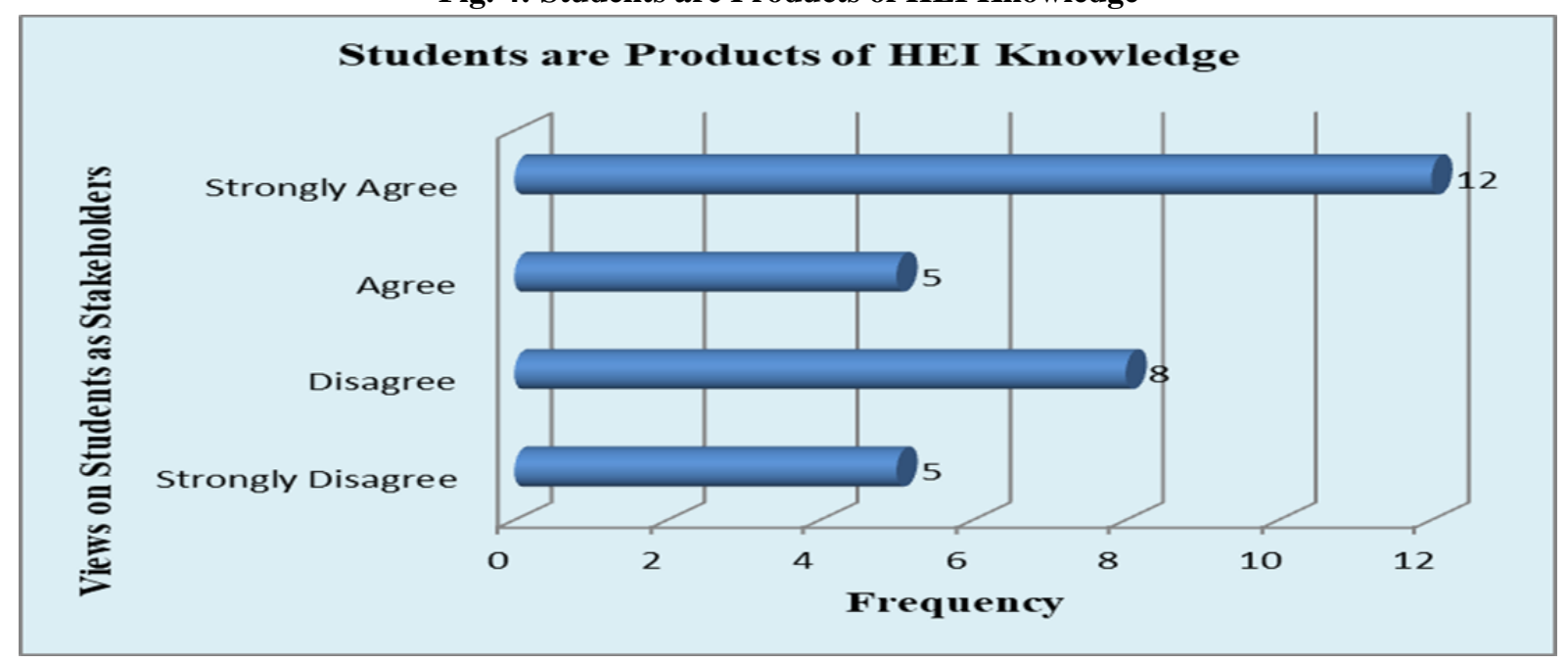

Asked whether students should be involved in quality assurance processes as the products of HEI knowledge and processes, quality assurance managers respondents still contradicted each other as depicted above. Do HEI products get to evaluate processes that gave birth to it? A significant twelve (12) strongly agreed while five (5) agreed. Clearly a cumulative seventeen (17) believe students are 'mere HEI products'. This views negate on the need for student involvement as a product cannot evaluate processes that gave birth to it credibly. However, a further eight (8) disagreed with five (5) strongly disagreeing.to make a total of thirteen (13) who variously disagreed.

This result negates on quality assurance processes whose outcmes depend on students incolvment as co-producers, for example where they participate as University Councillors and Senators in policy making among HEIs. Paradoxically, such students are arguably unable to participate in processes designed to produce themselves as graduate and therefore products of the same HEI 
Unpacking the Paradox of Student-Involvement Quality Promotion Nexus: Knowing Where to Draw the Line and Implications Thereof

processes they participated in. There is need for separation of roles and functions to avert the paradox. The figure 5 below depicts the overwhelming responses that account for institutional perception of students as products of HEI knowledge and processes.

The figure 5: students as products of HEI knowledge

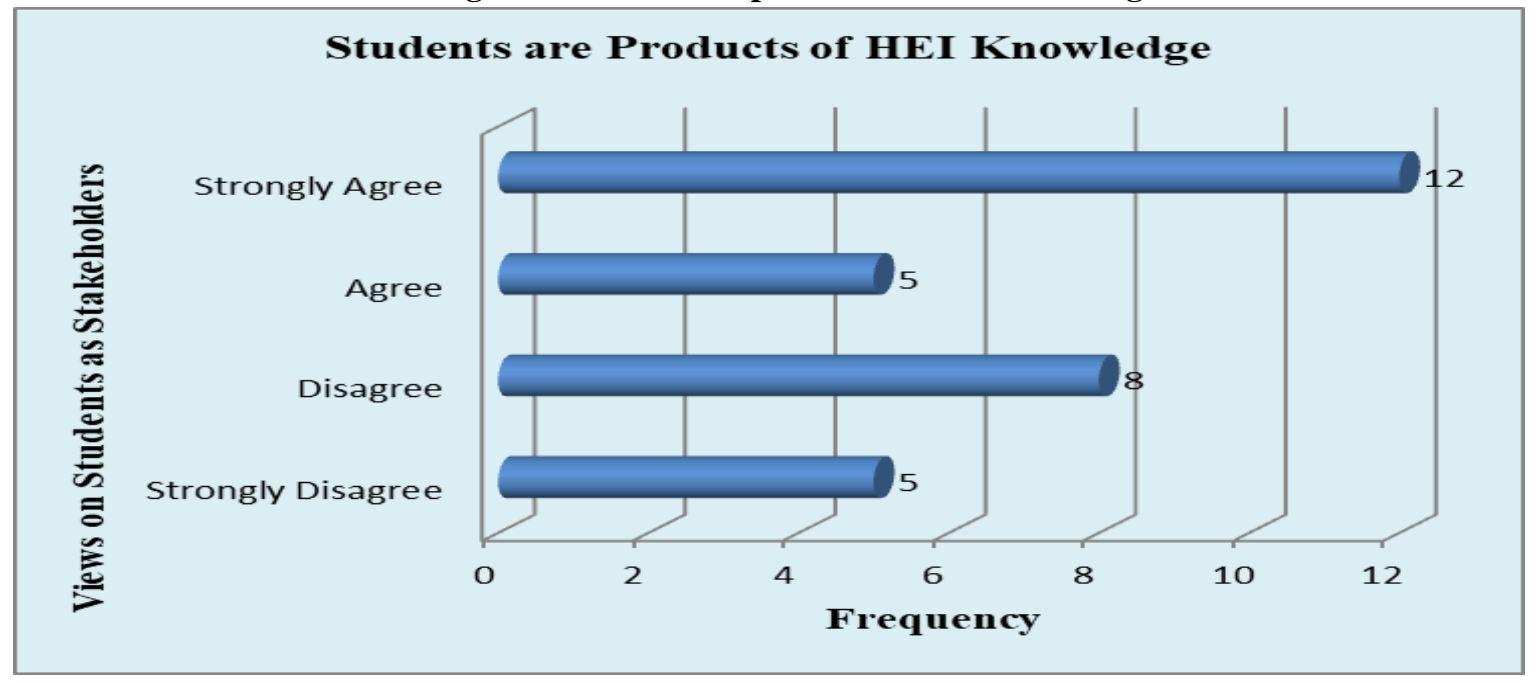

Fig. 6: Preferred Models of Student-Involvement among HEIs

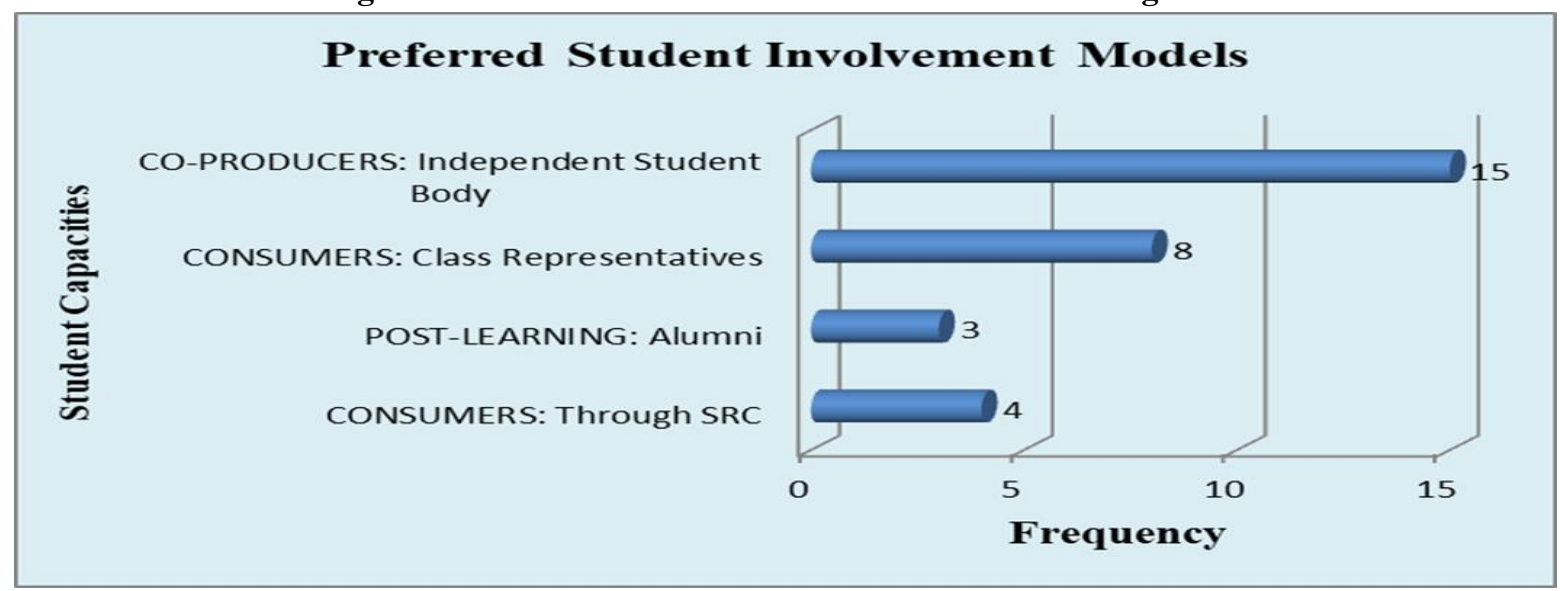

Figure 6 above demonstrates the paradoxical findings where respondents highlighted the disaggregated models of student involvement designed to abate the contraductions arsising from studets as co-producers; students as consumers; and lastly students as products, by using an independent student body (15) for all policy and governance related quality assurance issues among HEIs. This body could then consult each HEI SRC before engaging HEI management with meaningful contribution, yet without any compromise and contradiction of roles. Parallel student involvement as consumers at HEI level through class representatives (8); post-learning alumni (3) and lastly as consumers through the student representative council/student executive council (4) as the case may be.

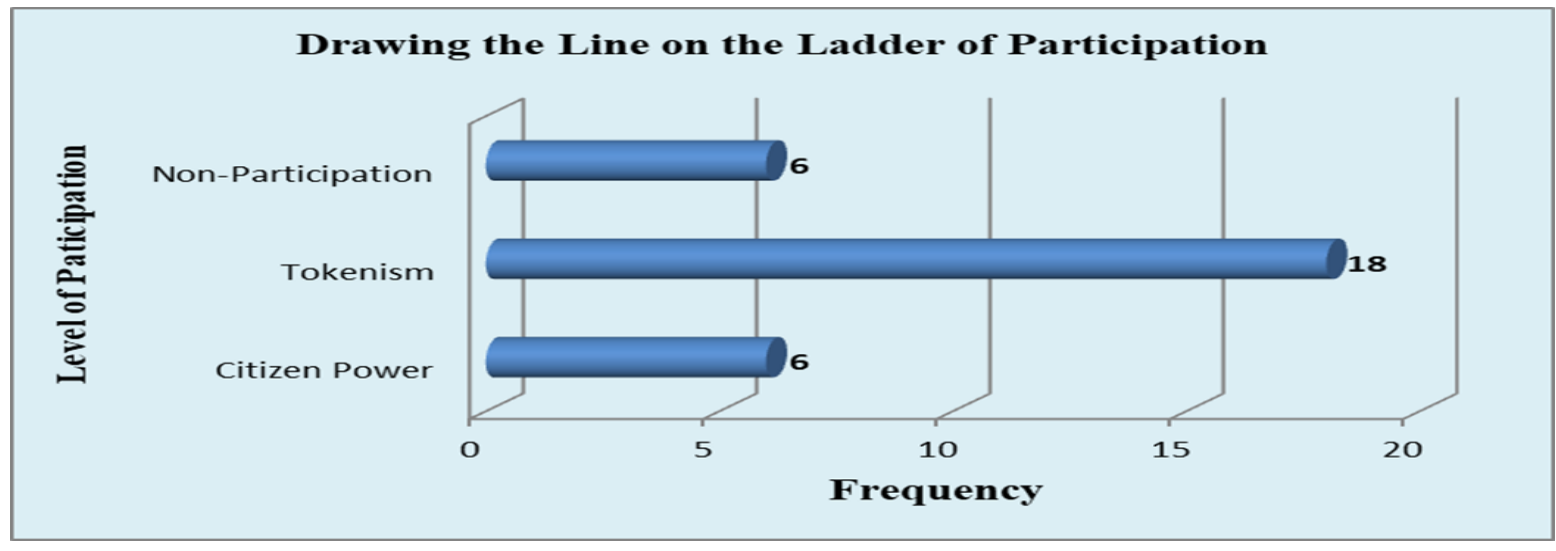


Responding to a question: Seeing therefore the contradictory capacities under which students should be involved in quality assurance processes, where should HEIs draw the line in the student involvement thrust to avert effects of contradictions affecting quality? Eighteen (18) respondents advocated for student involvement that is limited to the three centre rungs comprising Rung three, (Informing), Rung four (Consultation), and Rung five (Placation) that collectively make up tokenism (token-power-sharing). This is a far cry from the desired participation levels comprising Partnership (Rung Six), Delegated Power (Rung Seven) and Citizen Control (Rung Eight) respectively.

Fig. 7: Drawing the Line on the Ladder of Participation

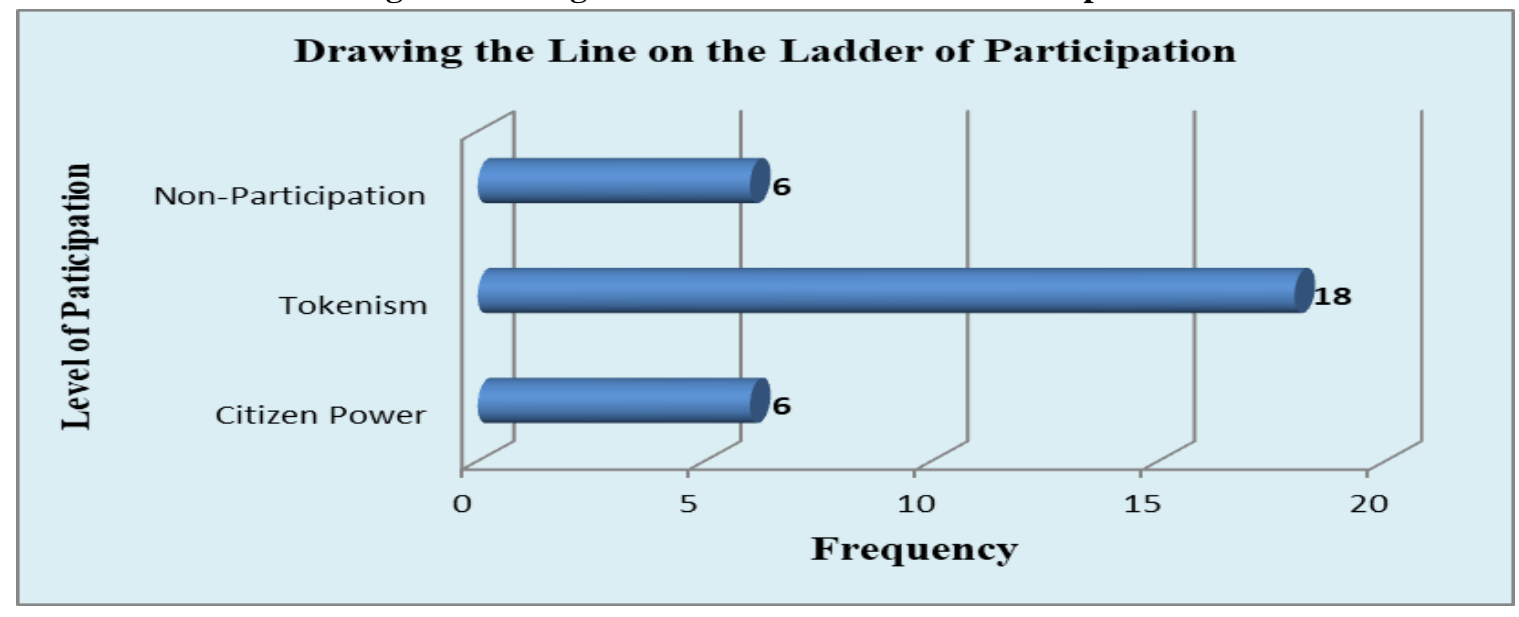

\section{SUMMARY OF FINDINGS}

Clearly, the student involvement domain is marred by grey patches. Various capacities emerge, whether they are participating in governance and quality assurance of higher education institutions as co-producers, consumers or products. Students as 'coproducers' they cannot produce themselves as 'students as products', neither can they be 'consumers' themselves while being the 'product' to be consumed by industry and communities. To minimise compromise on quality sought, students invigilating put their certificates at stake if they are caught in any foul play while cancellation of the invigilators' and exam-sitting student's certificate if caught in any foul play are measures to ensure student involvement and quality assurance.

\section{CONCLUSION}

Contradictions from student involvement in HEI quality assurance processes

Student involvement is marred by the lack of one clear approach for the desirable cause as they occupy many positions within higher education that call for different approaches.

\section{Student involvement cut-off level in HEI participation}

Informed by an opaque identity of students and their involvement in their contradictory capacities, student involvement is limited to the bottom five rungs, with the centre three rungs 'at best' while the lower two rungs 'at worst'. It is evident from the literature and from student that there is an overwhelming case for building processes and practices that are more participative, democratic, mutually respectful and learner-centred. However, while the literature provides evidence of the benefits of this approach, alongside interest and motivation in the sector to develop inclusive practices, the current context of teaching and learning in HEIs in most countries may constrain or at least challenge such relationships between staff and students, and the institutional processes necessary for everyone's benefit to develop new ways of working "genuinely enabling student-driven quality, participation and democratic professional practice" (Crawford 2012, 67).

\section{RECOMMENDATIONS}

This section recommends measures necessary for the policy making, implememtation, and further research levels:

Policy Level: Parliament/ The Ministry of Higher and Tertiary Education, Innovation, Science, and Technology Development (MoHTEISTD)

The National Assembly should address contradictions through amending HEI-establishing Acts to cede policy making powers to the University Councilsacting jointly with senior management of universities. 


\section{Unpacking the Paradox of Student-Involvement Quality Promotion Nexus: Knowing Where to Draw the Line and Implications Thereof}

\section{Implementation Level: HEIs}

The Ministry of Higher and Tertiary Education, Innovation, Science, and Technology Development should enact policies and procedures that address the contradictions in the Act when operationalising.

As co-producers, students involvement should be unlimited at governance levels (by different HEI students) while as consumers (within particular HEIs), student involvement should be limited to lower rungs at consumer level to avoid contradictions that potentially compromise quality.

As HEI products, students should be limited to Alumni activities as main function should clearly differentiate among the various roles when crafting HEI policies that foster student involvement.

\section{ACKNOWLEDGEMENTS}

Authors pay homage to the Council on Higher Education (CHE), South Africa for affording them the opportunity to present at their 26-28 February 2020 at CSIR International Convention Centre in Pretoria. They also extend the same gratitude to Gwanda State University for th chance to represent the institution to present at such a prestigious academic Conference.

\section{REFERENCES}

1) Alaniska, H., Arboix C.E., Bohrer, J., Dearlove, R., Ericsson, S., Helle, E. \& Wiberg, K., (Eds.), 2006. Student Involvement in the Process of Quality Assurance Agencies, Helsinki, Finland: European Association for Quality Assurance in Higher Education.

2) Bay, D. and Daniel, H. (2001) 'The Student Is Not the Customer - An Alternative Perspective' Journal of Marketing for Higher Education, 11(1), 1-19.

3) Barnes, H. and Bohrer, J., 2015. 'Engaging Professionally: Who does quality?' in B. Cunningham (ed.) Professional Life in Modern British Higher Education, 61-75, London: Institute of Education Press.

4) Biesta, G., 2015. 'What is Education For? On Good Education, Teacher Judgement, and Educational Professionalism', European Journal of Education, 50(1), 75-87.

5) BIS, 2016. Success as a Knowledge Economy, London: Department for Business Innovation and Skills.

6) Bitner, M.J., Faranda, W.T., Hubert, A.R., Zeithaml, V.A., 1997. "Customer Contributions and Roles in Service Delivery", International Journal of Service Industry Management, Vol. 8 No.3, pp.193-205.

7) Bramming, P., 2007. 'An argument for Strong Learning in Higher Education', Quality in Higher Education, 13(1), 45-56.

8) Browne, J., 2010. Securing a sustainable future for higher education: an independent review of higher education funding and student finance. Available at: www.independent.gov.uk/browne-report

9) Bunce, L., Baird, A. \& Jones, S.E., 2017. The Student-as-Consumer Approach in Higher Education and its Effects on Academic Performance, Studies in Higher Education, 42:11,19581978,DOI:10.1080/03075079.2015.1127908.https://doi.org/10.1080/0307 5079.2015.1 127908

10) Coates, H., 2005. The Value of Student Engagement for Higher Education Quality Assurance. Quality in Higher Education.

11) Coates, H., 2007. A model of online and general campus-based student engagement. Assessment and Evaluation in Higher Education.

12) Cook-Sather, A., 2009. From traditional accountability to shared responsibility: the benefits and challenges of student consultants gathering midcourse feedback in college classrooms. Assessment and Evaluation in Higher Education.

13) Cousin, G., 2008. New forms of transactional curriculum inquiry. In: R Land, JHF Meyer and J Smith (eds). Threshold concepts in the disciplines. Rotterdam: Sense Publications.

14) Crawford, K., 2012. Rethinking the student-teacher nexus: students as consultants on teaching in higher education. In: M Neary, H Stevenson and L Bell (eds). Towards teaching in public: reshaping the modern university. London: Continuum.

15) Cunningham, B., 2015. 'Enhancing 'Quality' in the Academy: Some Tensions and Contradictions' in Cunningham, B. (ed.) Professional Life in Modern British Higher Education, 41-60, London: Institute of Education Press.

16) Dearing, R., 1997. Higher Education in the Learning Society: Report of the National Committee of Inquiry into Higher Education. London: Her Majesty's Stationary Office. 
17) Department for Education and Skills (DfES) (2003). The future of higher education. London: The Stationery Office.

18) Eagle, L. and Brennan, R., 2007. Are Students Customers? TQM and Marketing Perspectives. Quality Assurance in Education 15, no. 1: 44-60.

19) Elwick, A. and Cannizzaro, S., 2017. 'Happiness in Higher Education', Higher Education Quarterly, 71(2), 204219.

20) Finney, T., and Finney, R., 2010. "Are Students Their Universities' Customers? An Exploratory Study." Education and Training 52 (4): 276-91.

21) Gapp, R. and Fisher, R., 2006. Achieving excellence through innovative approaches to student involvement in course evaluation within the tertiary education sector. Quality Assurance in Higher Education.

22) Gvaramadze, I., 2011. Student engagement in the Scottish quality enhancement framework. Quality in Higher Education.

23) Hénard, F. and Mitterle, A., 2009. Governance and Quality Guidelines in Higher Education: A review on governance arrangements and quality assurance guidelines.

24) Hennig-Thurau, T., Langer, M.F., Hansen, U., 2001. "Modeling and Managing Student Loyalty: An Approach Based on the Concept of Relationship Quality", Journal of Service Research, Vol. 3 No.4, pp.331-44.

25) Hynes, M. 2018. Students-as-Producers: Developing Valuable Student-Centered Research and Learning Opportunities, International Journal of Research Studies in Education, 2018 Volume 7 Number 4, 1-13, DOI: 10.5861/ijrse.2017.1858 ISSN: 2243-770

26) Jonassen, D.H. \& Easter, M.A., 2012. Conceptual Change and Student-Centered Learning Environments. In D. H. Jonassen \& M. A. Easter (Eds.), Theoretical foundations of Learning environments (2nd ed., pp. 95-113). New York, NY and Oxon, UK: Routledge.

27) Kandiko, C.B. and Mawer, M., 2013. Student Expectations and Perceptions of Higher Education. London: Kings Institute.

28) Kennedy, K.J., 2003. Higher Education Governance as a Key Policy Issue in the $21^{\text {st }}$ Century, in Educational Research for Policy and Practice, Vol. 2, No. 1, Springer Netherlands, pp. 55-70.

29) Kotzé, T.G. \& Du Plessis, P.J., 2003. 'Students as "co-producers" of education: a proposed model of student socialisation and participation at tertiary institutions', Quality Assurance in Education, vol. 11, no. 4, pp. 186201. http://www.emeraldinsight.com/Insight/view Container.do?containerType=Journal\&containerId=10951

30) Lesnik-Oberstein, K., 2015. "Let UK Universities Do What They Do Best - Teaching and Research." The Guardian, Letters, July 6. http://www.theguardian.com/education/2015/jul/06/let-uk-universities-do-what-they-do-bestteaching-and-research.

31) Little, B. and Williams, R., 2010. Students' roles in maintaining quality and in enhancing learning: is there a tension? Quality in Higher Education.

32) Lizzio, A. and Wilson, K., 2009. Student participation in university governance: the role conceptions and sense of efficacy of student representatives on departmental committees. Studies in Higher Education.

33) Hamshire, C. Forsyth, R., Bell, A., Benton, M., Kelly-Laubscher, R. Paxton, M. and Wolfgramm-Foliaki, E., 2017. 'The potential of student narratives to enhance quality in higher education', Quality in Higher Education, 23(1), 53-64

34) Harvey, L. and Williams, J., 2010. 'Fifteen Years of Quality in Higher Education', Quality in Higher Education, 16(1), 3-36.

35) Harvey, L. and Green, D., 1993. 'Defining Quality', Assessment and Evaluation in Higher Education, 18(1), 934.

36) McMahon, T. \& O'Neill, G., 2005. Student-Centered Learning: What does it mean for Students and Lecturers? In G. O'Neill, S. Moore, \& B. McMullin (Eds.), Emerging issues in the practice of university learning and teaching (pp. 27-36). Dublin, Ireland: All Ireland Society for Higher Education (AISHE).

37) Nair, C.S., Bennett, L. and Mertova, P., 2010. Responding to the Student Voice: a case study of a systematic improvement strategy. The TQM Journal.

38) Ness, M.K. and Osborn, T.A., 2010. 'Would you like fries with that? The dangers of the customer service model of reading teacher education', Critical Inquiry in Language Studies, 7(4), 334-348. 
39) Pascarella, ET, Sefifert, T.A. and Blaich, C., 2010. How Effective are NSSE Benchmarks in Predicting Important Educational Outcomes? Change: The Magazine of Higher Learning.

40) Richardson, J.T.E. (2005). 'Instruments for obtaining student feedback: a review of the literature',Assessment and Evaluation in Higher Education, 30(4), 387-415.

41) Race, P., 2015. The Lecturer's Toolkit: A Practical Guide to Assessment, Learning and Teaching (4th ed.). Oxon, UK and New York, NY: Routledge.

42) Roslöf, J., 2018. Students' Participation in Degree Program-Level Quality Assurance Activities, Turku, Finland: Faculty of Engineering and Business, Turku University of Applied Sciences, https://www.researchgate.net/publication/327803125

43) Sabin, J.E. and Daniels, N. 2001. Managed care: strengthening the consumer voice in managed care. Psychiatric Services.

44) Scott, E.A., 2018. Student involvement in the quality assurance processes in HE in FE: perceptions of students, teachers and managers. A thesis submitted in partial fulfillment of the requirements of the Institute of Education, University of London for the degree of Doctor in Education.

45) Staddon, E. and Standish, P., 2012. 'Improving the Student experience', Journal of Philosophy of Education, 46(4), 631-648.

46) Tomlinson, M., 2016. "Students' Perception of Themselves as'Consumers' of Higher Education."Britis Journal of Sociology of Education. doi:10.1080/01425692.2015.1113856.

47) Tomlinson, M., 2014. Exploring the Impacts of Policy Changes on Student Attitudes to Learning. York: Higher Education Academy. 50 pp.

48) Trowler, V., 2010. Student engagement literature review. York: Higher Education Academy.

49) Trowler, V. and Trowler, P., 2010. Student engagement evidence summary. York: Higher Education Academy.

50) Umbach, P.D. and Wawrzynski, M.R., 2005. Faculty do matter: the role of college faculty in student learning and engagement. Research in Higher Education.

51) Woodall, T., Hiller, A. and Resnick, S., 2011. Making Sense of Higher Education: Students as Consumers and the Value of the University Experience

52) Wyns, V., Van Hemelrijck, I., Londers, E. \& Berbers, Y., 2015. Student and Industry Involvement in Quality Assurance, 43rd Annual SEFI Conference, Orléans, France.

53) Fadeeva, Z.; Galkute, L.; Mader, C.; Scott, G., 2014. Sustainable Development and Quality Assurance in Higher Education; Palgrave Macmillan: Houndmills, UK, 2014

54) Gvaramadze, I., 2011. Student engagement in the Scottish quality enhancement framework. Quality in Higher Education.

55) Little, B. and Williams, R., 2010. Students' roles in maintaining quality and in enhancing learning: is there a tension? Quality in Higher Education.

56) Lizzio, A. and Wilson, K., 2009. Student participation in university governance: the role conceptions and sense of efficacy of student representatives on departmental committees. Studies in Higher Education.

57) Hamshire, C. Forsyth, R., Bell, A., Benton, M., Kelly-Laubscher, R. Paxton, M. and Wolfgramm-Foliaki, E., 2017. 'The potential of student narratives to enhance quality in higher education', Quality in Higher Education, 23(1), 53-64.

58) Nair, C.S., Bennett, L. and Mertova, P., 2010. Responding to the student voice: a case study of a systematic improvement strategy. The TQM Journal.

59) Ness, M.K. and Osborn, T.A., 2010. 'Would you like fries with that? The dangers of the customer service model of reading teacher education', Critical Inquiry in Language Studies, 7(4), 334-348.

60) Hynes, M., 2018. Students-as-producers: Developing valuable student-centered research and learning opportunities, 2018 International Journal of Research Studies in Education, Volume 7 Number 4, 1-13

61) Light, G., Calkins, S., \& Cox, R., 2009. Learning and teaching in higher education: The reflective professional (2nd ed.). London, UK: Sage Publications Ltd.

62) Salvioni DM, Franzoni S, Cassano R. Article: Sustainability in the Higher Education System- An Opportunity to Improve Quality and Image, 2017. www.sustainabilitytreaties.org

63) Sabin, J.E. and Daniels, N., 2001. Managed care: strengthening the consumer voice in managed care. Psychiatric Services. 
Unpacking the Paradox of Student-Involvement Quality Promotion Nexus: Knowing Where to Draw the Line and Implications Thereof

64) Scott, E.A., 2018. Student involvement in the quality assurance processes in HE in FE: perceptions of students, teachers and managers. A thesis submitted in partial fulfillment of the requirements of the Institute of Education, University of London for the degree of Doctor in Education.

65) Staddon, E. and Standish, P., 2012. 'Improving the Student experience', Journal of Philosophy of Education, 46(4), 631-648.

66) Trowler, V., 2010. Student engagement literature review. York: Higher Education Academy.

67) Trowler, V. and Trowler, P., 2010. Student engagement evidence summary. York: Higher Education Academy.

68) Umbach, PD. and Wawrzynski, M.R., 2005. Faculty do matter: the role of college faculty in student learning and engagement. Research in Higher Education. 